(1) 1986 ISIJ

機能性金属めつきき解説

\title{
Functional Metal Plating
}

\section{Tadao HAYASHI}

1.はじめに

機能性金属めつきは通常機能めつきと呼ばれ，めつき 皮膜の特性, たとえば硬さ, 強度, 耐摩耗性, 耐食性, 電導性，はんだづけ性などに応じていろいろの用途が開 発されている.

従来，めつき皮膜は1）装飾用，2）防食用，3）装飾 兼防食用，4）工業用に大別されていたが，めつき皮膜の 多様化に伴い，また，新しい皮膜の特性が注目されるよ らになつて，それぞれの機能に応じためつき皮膜の分類 が行われるよらになつた.

各種の金属めつき皮膜をその機能的因子によつて分類 すると表1のようになる1'.
このような機能めつきは単一金属のめつき, あるいは 合金めつきによつてその機能が付与されるが，最近では 分散めつき（複合めつき）などの新しいめつきプロセス によつて各種の機能めつきが出現している1). とくに, 分散めつきは金属マトリックスと非金属（金属酸化物, 炭化物，けい化物など）あるいは有機化合物をめつき皮 膜中に均一に分散共析させることによつて，いままで考 えられなかつた特性を持つためつき皮膜が得られ，その 応用面でも新しい分野が開かれている. 表 2 に各種の分 散剤を示す.

ここでは主として金属素材に対するめつき皮膜として 注目されている各種の機能めつきについて述べる.

表 1 機能めつきの種類

\begin{tabular}{|c|c|c|c|}
\hline \multirow{19}{*}{ 機能めつき } & \multirow{5}{*}{ 機械的 } & 1) 耐摩耗, 耐摩擦性皮膜 & $\begin{array}{l}\text { 硬啠 } \mathrm{Cr}, \mathrm{Ni}-\mathrm{P}, \mathrm{Ni}-\mathrm{SiC}, \mathrm{Ni}-\mathrm{BN}, \\
\mathrm{Co}_{0}-\mathrm{Cr}_{3} \mathrm{C}_{2}, \mathrm{Ni}-\mathrm{B}{ }_{4} \mathrm{C}, \mathrm{Ni}-\mathrm{P}-\mathrm{SiC}\end{array}$ \\
\hline & & 2) 自己潤滑性皮膜 & 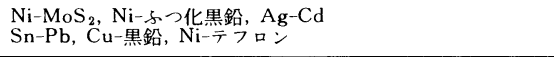 \\
\hline & & 3）工業用ニッケルおよび鉄めつき & 厚うけ $\mathrm{Ni}$, 硬質 $\mathrm{Fe}$ \\
\hline & & 4) 分散強化合金めつき & $\mathrm{Ni}-\mathrm{Al}_{2} \mathrm{O}_{3}, \mathrm{Ni}-\mathrm{TiO}_{2}, \mathrm{Fe}-\mathrm{Al}_{2} \mathrm{O}_{3}, \mathrm{Ni}-\mathrm{Cr}$ \\
\hline & & 5) 電鋳 & $\mathrm{Cu}, \mathrm{Ni}, \mathrm{Al}, \mathrm{W}, \mathrm{Mo}, \mathrm{TiB}_{2} \mathrm{Ni}-\mathrm{Fe}-\mathrm{Co}$ \\
\hline & \multirow{5}{*}{ 電気的 } & 6) 電導性皮膜 & プラスチックめつき,プリント基盤 \\
\hline & & 7) 電気接点 & $\mathrm{Au}, \mathrm{Au}-\mathrm{Co}_{0}, \mathrm{Au}-\mathrm{Ni}, \mathrm{Au}-\mathrm{TiC}, \mathrm{Au}-\mathrm{WC}, \mathrm{Ag}-\mathrm{Cu}, \mathrm{Sn}-\mathrm{Ni}$ \\
\hline & & 8) 電気抵抗皮膜 & $\mathrm{Ni}-\mathrm{P}, \mathrm{Ni}-\mathrm{B}, \mathrm{Ni}-\mathrm{Co}_{0}-\mathrm{B}, \mathrm{Ni}-\mathrm{Mo}-\mathrm{B}, \mathrm{Ni}-\mathrm{Mo}-\mathrm{P}$ \\
\hline & & 9)はんだめつき & $\mathrm{Sn}, \mathrm{Sn}-\mathrm{Pb}, \mathrm{In}$ \\
\hline & & 10) 超電導体 & $\mathrm{Nb}, \mathrm{Nb}_{3}-\mathrm{Zr}, \mathrm{Pb}-\mathrm{Bi}$ \\
\hline & 磁気的 & 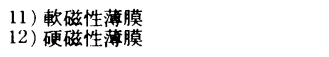 & $\begin{array}{l}\mathrm{Ni}-\mathrm{Fe}(\stackrel{-}{2}-\text { マ只 } 1), \mathrm{Ni}-\mathrm{Fe}-\mathrm{Co} \\
\mathrm{Co}-\mathrm{P}, \mathrm{Ni}-\mathrm{Co}-\mathrm{P}, \mathrm{Co}-\mathrm{Fe}-\mathrm{P}\end{array}$ \\
\hline & \multirow{3}{*}{ 化学的 } & 13）耐食性皮膜 & $\begin{array}{l}\text { a) } \mathrm{Zn}, \mathrm{Cd}, \mathrm{Pb}, \mathrm{Zn} \text { 合金 } \\
\text { b) } \mathrm{Cr}-\mathrm{Ni}-\mathrm{Fe}, \mathrm{Sn}-\mathrm{Ni} \\
\text { c) } \mathrm{Pt}, \mathrm{Ir}, \mathrm{Os}, \mathrm{Ta}, \mathrm{Nb}, \mathrm{W}\end{array}$ \\
\hline & & 14) 分散めつき & $\mathrm{Zn}$-エポキシ墈脂, $\mathrm{Zn}$-スチレンブタジエン共重合体 \\
\hline & & 15) 電栖材料 & $\mathrm{Ni}-\mathrm{TiO}_{2}, \mathrm{Ni}-\mathrm{ZrO}_{2}, \mathrm{Ni}-\mathrm{S}, \mathrm{Ni}-\mathrm{B}, \mathrm{Ni}-\mathrm{P}, \mathrm{Pt} / \mathrm{Ta}$ 複層めつき \\
\hline & \multirow{3}{*}{ 光学的 } & 16）装飾めつき & $\mathrm{Cu}-\mathrm{Ni}-\mathrm{Cr}, \mathrm{Sn}-\mathrm{Ni}, \mathrm{Sn}-\mathrm{Co}, \mathrm{Au}$, 金合金 \\
\hline & & 17) カラーめつき & $\mathrm{Ni}$-螢光顔料，着色 $\mathrm{Cr}$ \\
\hline & & 18) 光電変換用皮膜 & $\mathrm{CdS}, \mathrm{Si}, \mathrm{Ge}, \mathrm{Cd}-\mathrm{Te}$ \\
\hline & \multirow{2}{*}{ 熱 的 } & 19）太陽熱選択吸収皮膜 & 黒色 $\mathrm{Cr}_{r}$, 黒色 $\mathrm{Ni}$, 黒色 $\mathrm{Cr}-\mathrm{Co}$, 黒色無電解 $\mathrm{Ni}$ \\
\hline & & 20) 耐熱性皮膜 & $\mathrm{Cr}-\mathrm{Ni}, \mathrm{Ni}-\mathrm{W}, \mathrm{Co}-\mathrm{W}, \mathrm{Ni}-\mathrm{Mo}, \mathrm{Co}_{0}-\mathrm{Mo}_{0}, \mathrm{Cr}-\mathrm{Ni}-\mathrm{Fe}$ \\
\hline
\end{tabular}

昭和 60 年 10 月 16 日受付 (Received Oct. 16, 1985) （依頼解説）

* 大阪府立大学工学部 工博 (College of Engineering, University of Osaka Prefecture, 4-804 Mozu-Umemachi Sakai 591) 
表 2 分散めつきの粒子と金属マトリックス

\begin{tabular}{|c|c|}
\hline $\begin{array}{l}\text { マトリ } \\
\text { ックス }\end{array}$ & 分 散 粒子 \\
\hline $\mathrm{Ni}$ & 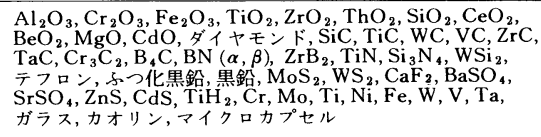 \\
\hline $\mathrm{Cu}$ & 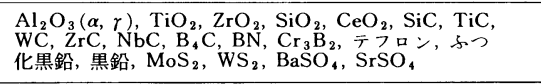 \\
\hline Co & $\begin{array}{l}\mathrm{Al}_{2} \mathrm{O}_{3}, \mathrm{Cr}_{2} \mathrm{O}_{3}, \mathrm{Cr}_{3} \mathrm{C}_{2}, \mathrm{WC}, \mathrm{TaC}, \mathrm{ZrB}_{2}, \mathrm{BN}, \\
\mathrm{Cr}_{3} \mathrm{~B}_{2}, \text { ダイヤモンド }\end{array}$ \\
\hline $\mathrm{Fe}$ & $\mathrm{Al}_{2} \mathrm{O}_{3}, \mathrm{Fe}_{2} \mathrm{O}_{3}, \mathrm{SiC}, \mathrm{WC}, \mathrm{B}$, テフロン, $\mathrm{MoS}_{2}$ \\
\hline $\mathrm{Cr}$ & $\begin{array}{l}\mathrm{Al}_{2} \mathrm{O}_{3}, \mathrm{CeO}_{2}, \mathrm{ZrO}_{2}, \mathrm{TiO}_{2}, \mathrm{SiO}_{2}, \mathrm{UO}_{2}, \mathrm{SiC}, \mathrm{WC}, \\
\mathrm{ZaB}_{2}, \mathrm{TiB}_{2}\end{array}$ \\
\hline $\mathrm{Au}$ & $\begin{array}{l}\mathrm{Al}_{2} \mathrm{O}_{3}, \mathrm{Y}_{2} \mathrm{O}_{3}, \mathrm{SiO}_{2}, \mathrm{TiO}_{2}, \mathrm{ThO}_{2}, \mathrm{CeO}_{2}, \mathrm{TiC}, \mathrm{WC}, \\
\mathrm{Cr}_{3} \mathrm{~B}_{2}\end{array}$ \\
\hline $\mathrm{Ag}$ & $\mathrm{Al}_{2} \mathrm{O}_{3}, \mathrm{TiO}_{2}, \mathrm{BeO}, \mathrm{SiC}, \mathrm{BN}, \mathrm{MoS}_{2}$, コランダム, 黒鉛 \\
\hline $\mathrm{Zn}$ & $\mathrm{ZrO}_{2}, \mathrm{SiO}_{2}, \mathrm{TiO}_{2}, \mathrm{Cr}_{2} \mathrm{O}_{3}, \mathrm{SiC}, \mathrm{TiC}, \mathrm{Cr}_{3} \mathrm{C}_{2}, \mathrm{Al}$ \\
\hline $\mathrm{Cd}$ & $\mathrm{Al}_{2} \mathrm{O}_{3}, \mathrm{Fe}_{2} \mathrm{O}_{3}, \mathrm{~B}_{4} \mathrm{C}$, コランダム \\
\hline $\mathrm{Pb}$ & $\mathrm{Al}_{2} \mathrm{O}_{3}, \mathrm{TiO}_{2}, \mathrm{TiC}, \mathrm{BC}, \mathrm{Si}, \mathrm{Sb}$, コランダム \\
\hline Sn & コランダム \\
\hline $\mathrm{Ni}-\mathrm{Co}$ & $\mathrm{Al}_{2} \mathrm{O}_{3}, \mathrm{SiC}, \mathrm{Cr}_{3} \mathrm{C}_{2}, \mathrm{BN}$ \\
\hline $\mathrm{Ni}-\mathrm{Fe}$ & $\mathrm{Al}_{2} \mathrm{O}_{3}, \mathrm{Eu}_{2} \mathrm{O}_{3}, \mathrm{SiC}, \mathrm{Cr}_{3} \mathrm{C}_{2}, \mathrm{BN}$ \\
\hline $\mathrm{Ni}-\mathrm{Mn}$ & $\mathrm{Al}_{2} \mathrm{O}_{3}, \mathrm{SiC}, \mathrm{Cr}_{3} \mathrm{C}_{2}, \mathrm{BN}$ \\
\hline $\mathrm{Pb} \cdot \mathrm{Sn}$ & $\mathrm{TiO}_{2}$ \\
\hline $\mathrm{Ni}-\mathrm{P}$ & $\begin{array}{l}\mathrm{Al}_{2} \mathrm{O}_{3}, \mathrm{Cr}_{2} \mathrm{O}_{3}, \mathrm{TiO}_{2}, \mathrm{ZrO}_{2}, \mathrm{SiC}, \mathrm{Cr}_{3} \mathrm{C}_{2}, \mathrm{~B}_{4} \mathrm{C}, \\
\text { ダイヤモンド, テフロン, } \mathrm{BN}, \mathrm{CaF}_{2}\end{array}$ \\
\hline $\mathrm{Ni}-\mathrm{B}$ & $\mathrm{Al}_{2} \mathrm{O}_{3}, \mathrm{Cr}_{2} \mathrm{O}_{3}, \mathrm{SiC}, \mathrm{Cr}_{3} \mathrm{C}_{2}$, ダイヤモンド \\
\hline $\mathrm{Co}-\mathrm{B}$ & $\mathrm{Al}_{2} \mathrm{O}_{3}, \mathrm{Cr}_{2} \mathrm{O}_{3}, \mathrm{BN}$ \\
\hline
\end{tabular}

\section{2. 耐摩耗，耐摩擦性皮膜}

機械部品の耐摩耗, 耐摩擦性を目的としためつき皮膜 としてはすでに古く硬質クロムめつきがピストンシリン ダー, ピストンリング，シャフトなどに広く用いられて いる.このようなクロムめつきはその皮膜の硬さ,強度， 耐摩耗性が優れていることによる.

近年，機械部品に適用してその耐摩耗性あるいは耐摩 擦性を向上させる目的で各種の分散めつきが開発されて いる.

ニッケルをマトリックスとした Ni-SiG 分散めつきは ドイッで開発されたもので2), WANKEL MoTOR 社では Elnisil 法3), MABLE 社では Nikasil プロセス4) として 製品化しているわが国では鈴木自工(株)が Ni-P-SiC 分散めつきを電解法で製造する方法を工業化し ${ }^{5)}$ ，自動 車エンジンシリンダーの耐摩耗性皮膜として実用化して いる6).

これらのニッケルめつき浴は析出速度の大きいスルフ フミン酸ニッケル浴を使用しており， Nikasil プロセス では 20-80 A/ $\mathrm{dm}^{2}$ で, 電流効率が $90 \%, 80 \mathrm{~A} / \mathrm{dm}^{2}$ で $16 \mu \mathrm{m} / \mathrm{min}$ の高速めつきが得られている.

分散剤として平均粒径 1-3 $\mu \mathrm{m}$ の $\mathrm{SiC}$ の浴中の濃度
として 35-90 g/l で用いると， 2.3-4.0 wt\% の $\mathrm{SiC}$ ニッケルマトリックス中に共析し, その硬さもワット浴 から電析したものより大きく, 摩耗量も少ないことか認 められている4).

$\mathrm{Ni}-\mathrm{SiC}$ 分散めつきについては実用化とともに基礎的 な研究子多( (7) 11).

イギリスの Bristol Aerojet 社で開発されたTribomet プロセス ${ }^{12)}$ ではコバルトをマトリックスとする分散 めつきの中で $\mathrm{Co}-\mathrm{Cr}_{3} \mathrm{C}_{2}, \mathrm{Co}-\mathrm{ZrB}_{2}, \mathrm{Co}-\mathrm{SiC}$ などが高 温で耐摩耗性がすぐれていることが実証され，とくに $\mathrm{Co}-\mathrm{Cr}_{3} \mathrm{C}_{2}$ 分散めつき $\left(\mathrm{Cr}_{3} \mathrm{C}_{2}\right.$ 約 $30 \mathrm{vol} \%$ 含有) が梳 空機エンジン部品に適用されている. $\mathrm{Co}-\mathrm{Cr}_{3} \mathrm{C}_{2}$ 分散め つきは $300^{\circ} \mathrm{C}$ 以上で接触摩擦面にガラス状の酸化コ: ルト層が生成し，耐摩耗性が維持されるといら特長があ り, 乾燥空気中において約 $800^{\circ} \mathrm{C}$ まで耐摩耗性のよい ことが報告されている13)。図1亿 Co および Ni をマ トリックスとした分散めつきの高温での耐摩耗性の変化 を示す.

最近 Тнома 5 14)15)は電着法による $\mathrm{Ni}$, Co ならび に無電解めつき法による Ni-P をマトリックスとしたダ イヤモンド， $\mathrm{Cr}_{2} \mathrm{O}_{3} 、 \mathrm{TiC}, \mathrm{SiC}$ などを分散剤としため つき皮膜について振動一摩擦摩耗試験を行い, Ni-P-ダイ ヤモンド皮膜は $20-400^{\circ} \mathrm{C}, \mathrm{Co}-\mathrm{Cr}_{2} \mathrm{O}_{3}$ 分散めつき皮膜 は 300-700 $\mathrm{C}$ で摩耗特性がすぐれていることを明らか にした。 (困 2 参照)

化学ニッケルめつきでは Ni-P あるいは Ni-B が析 出し, 熱処理 $\left(350-400^{\circ} \mathrm{C}\right)$ で皮膜の硬さが增大するの で，このような合金をマトリックスとする分散めつきは

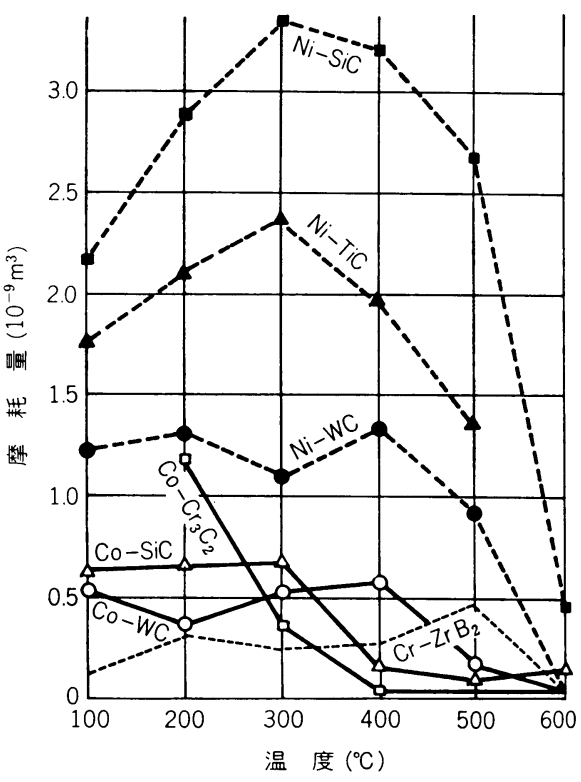

図 $1 \mathrm{Ni}$ 及び Co をマトリックスとする分散めつ きの高温での耐摩耗性 ${ }^{12)}$ 


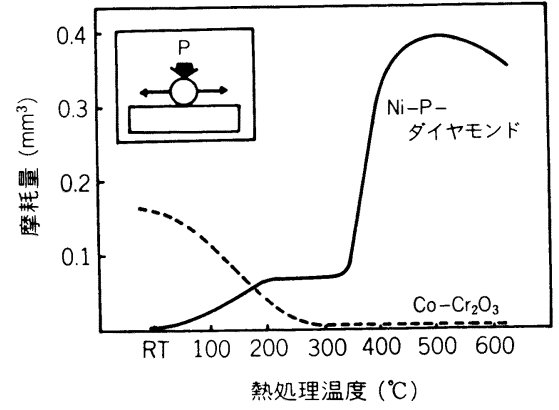

四 $2 \mathrm{Ni}-\mathrm{P}-$ ダイヤモンド及び $\mathrm{Co}-\mathrm{Cr}_{2} \mathrm{O}_{3}$ 分散めつ きの耐摩耗性

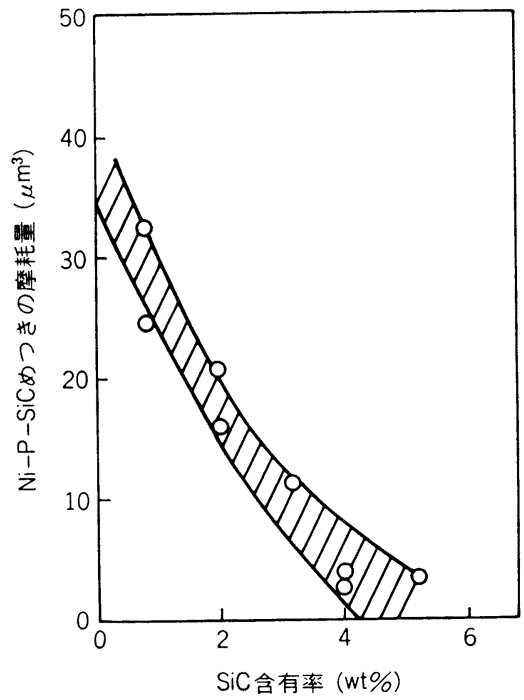

困 $3 \mathrm{Ni}-\mathrm{P}-\mathrm{SiC}$ 分散めつきの摩耗量と $\mathrm{SiC}$ 含有 率との関係 ${ }^{16)}$

硬さが大きく，耐摩耗性もすぐれている。

$\mathrm{Ni}-\mathrm{P}-\mathrm{SiC}$ 分散めつきの摩耗量は $\mathrm{SiC}$ 粒子の共析量 が増すと著しく減少し，また，皮膜の摩擦係数が小さ く, 密着性も寸ぐれている16) (図 3 参照).

FELDSTEIN ら 17)18)によると化学ニッケルめつき, Ni-P および Ni-B をマトリックスとし，多結晶合成ダイヤモ ンドを分散剂とした分散めつき皮膜は耐摩耗性，耐摩擦 性にすぐれており，紡系工程における耐摩耗部品に適用 できるといわれる.

化学めつきによる分散めつきの新しい試みとして 2 種 類の分散剤を同時に用いることによつて耐摩耗性が著し く向上することが報告されている(19).

DENNIS ら ${ }^{20)}$ は化学めつき法による $\mathrm{Ni}-\mathrm{P}-\mathrm{Cr}_{3} \mathrm{C}_{2}$ 分散 めつきの生成条件を検討し， $\mathrm{Cr}_{3} \mathrm{C}_{2}$ 約 $27 \%, \mathrm{P} 7.2 \%$ を含む分散めつきは熱処理により硬さが著しく向上し， Co-Mo 合金めつきに匹敵する耐摩耗性を示すことを明
らかにした。

なお，化学ニッケル分散めゔきの進歩については BROWN21）の総説がある.

電着合金をマトリックスとする耐摩耗性の分散めつき については $\mathrm{Ni}-\mathrm{Co}^{22)}, \mathrm{Ni}-\mathrm{Mn}^{23)}, \mathrm{Ni}-\mathrm{Fe}^{24)}$ などの合金 めつきを用いたものがある. Ni-Mn- $\mathrm{Al}_{2} \mathrm{O}_{3}, \mathrm{Ni}-\mathrm{Mn}-\mathrm{S}-$ $\mathrm{SiC}$ などの分散めつきはマトリックス自体の硬さも大き く, 分散剤の共析によつて一層硬さが増大し, 耐摩耗性 も向上することが認められている。

\section{3. 分散強化合金めつき}

分散めつきの最初の応用として考えられたのが分散強 化合金でいわゆるサーメットの製造25)26)があげられる. 分散強化合金としては $\mathrm{Ni}-\mathrm{Al}_{2} \mathrm{O}_{3}, \mathrm{Ni}-\mathrm{ZrO}_{2}, \mathrm{Ni}-\mathrm{MoSi}_{2}$, $\mathrm{Cu}-\mathrm{Al}_{2} \mathrm{O}_{3}, \mathrm{Co}-\mathrm{Al}_{2} \mathrm{O}_{3}, \mathrm{Co}-\mathrm{SiC}$ などが検討されている.

BROWN 5 27) は高温に打ける機械的性質のすぐれた $\mathrm{Fe}-\mathrm{Al}_{2} \mathrm{O}_{3}$ 分散強化合金について拡張力, 硬さの測定を 行い, とくに熱処理による特性の変化を明らかにした. 図 4 および阔 5 に $\mathrm{Al}_{2} \mathrm{O}_{3}$ の共析量と払張力および強さ の関係を示した。

CELIS ら ${ }^{28)}$ は酸性硫酸銅浴からの $\mathrm{Cu}-\mathrm{Al}_{2} \mathrm{O}_{3}$ 分散め

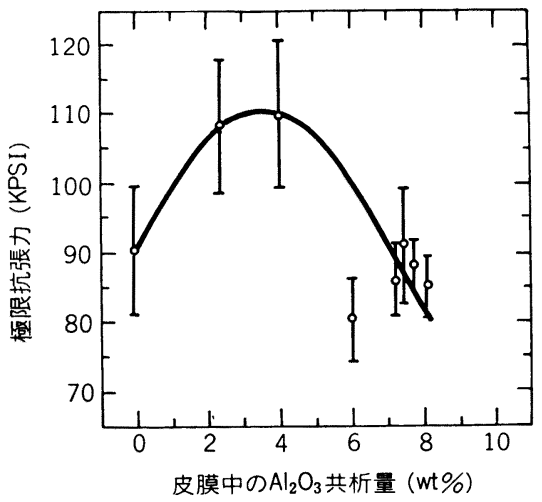

図 4 分散剂の共析量と極限抗張力 $\left(\mathrm{Fe}-\mathrm{Al}_{2} \mathrm{O}_{3} \text { めつき }\right)^{27)}$

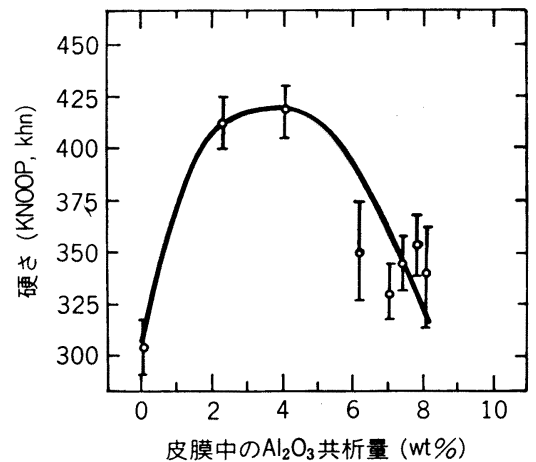

図 5 分散绪の共析量と硬さ $\left(\mathrm{Fe}-\mathrm{Al}_{2} \mathrm{O}_{3} \text { めつき) }\right)^{27)}$ 
つきについて検討し, 分散強化には $\gamma-\mathrm{Al}_{2} \mathrm{O}_{3}$ が適して いることを明らかにした。 なお， $\gamma-\mathrm{Al}_{2} \mathrm{O}_{3}$ は従来酸性浴 から共析しないと考えられていたが, SAUTER ら29)は $\gamma-\mathrm{Al}_{2} \mathrm{O}_{3}$ を椵焼 $\left(1125^{\circ} \mathrm{C}, 20 \mathrm{~h}\right)$ することにより，ま

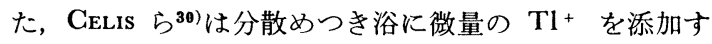
ることにより $\mathrm{Cu}-\mathrm{Al}_{2} \mathrm{O}_{3}$ 分散めつきを得ることに成功 した。

特殊な分散強化合金として鉛めつきのクリープ強度な らびに耐食性を向上させるために $\mathrm{Pb}-\mathrm{WC}, \mathrm{Pb}-\mathrm{TiC} な$ どの分散めつきを行つた報告がある31).

\section{4. 自己潤滑性めつき皮膜}

固体潤滑剂の微粒子を金属と共析させた分散めつきは 表面の摩擦係数が小さく, 皮膜自体の摩耗が少ないため に自己潤滑性皮膜として工業的に利用されている。

VEST ら ${ }^{32)}$ はスルファミン酸ニッケルめつき浴に $\mathrm{MoS}_{2}$ を分散剤として用い, $\mathrm{Ni}-\mathrm{MoS}_{2}$ 分散めつきの析出条件 を検討し, $\mathrm{MoS}_{2}$ 共析量がニッケルめつき浴のの $\mathrm{pH} の$ 低下, 電流密度の減少によつて増加することを明らかに した.

分散剂としてふつ化黒鉛, $(\mathrm{CF})_{n}$ を用いた $\mathrm{Cu}-(\mathrm{CF})_{n}$ および $\mathrm{Ni}-(\mathrm{CF})_{n}$ 分散めつきはいずれも $(\mathrm{CF})_{n}$ を $10-$ $15 \mathrm{vol} \%$ 含み, すぐれた耐摩耗, 耐摩擦性を示す33). 図 6 にワット浴を用いた場合の浴中の $(\mathrm{CF})_{n}$ 濃度と二ッ ケルめつき中への $(\mathrm{CF})_{n}$ の共析量を示す.このような $\mathrm{Ni}-(\mathrm{CF})_{n}$ 分散めつきは皮膜自体の摩耗だけでなく，摺 動相手のスチールの摩耗を非常に少なくすることが認め られ, 軽荷重の摺動部品への利用が期待されている34)35) (図 7 参照).

$\mathrm{Ni}-(\mathrm{CF})_{n}$ 分散めつきは鉄鋼連続鋳造用の鋳型の表面 処理に適用され，その寿命が著しくのびることが認めら れている36).

四ふつ化ェチレン（PTFE，テフロン）のすぐれた低 摩擦性, 潤滑性を利用した Ni-PTFE 分散めつき(PTFE $10-15 \%$ 含有) は硬さ $500-600 \mathrm{HV}(100 \mathrm{~g}$ 荷重) で潤

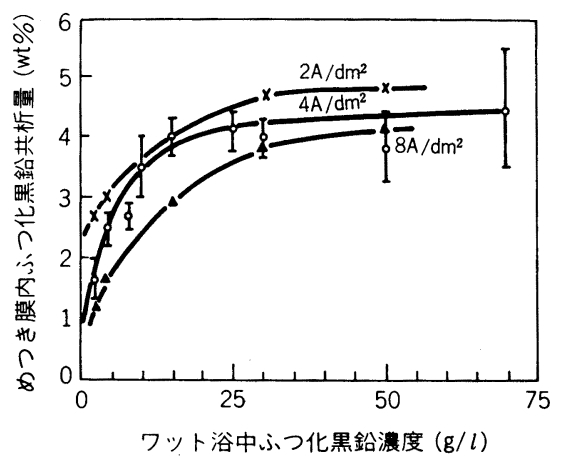

困 6 ふつ化黒鉛けん濁濃度とニッケルめつき 膜内共析量 ${ }^{33}$ )

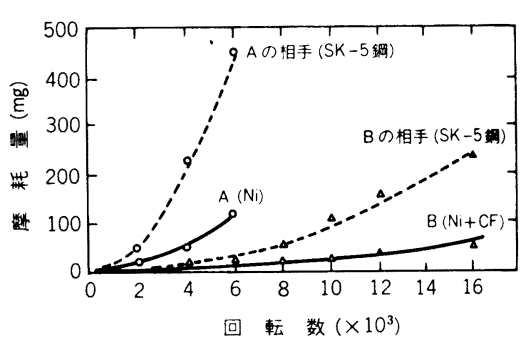

四 7 ふつ化黑鉛共析の耐摩耗効果 (西原式摩耗試験) ${ }^{33}$ )

表 3 悪鉛合金めつき鋼板

\begin{tabular}{|c|c|c|c|}
\hline 合金系 & 組 & 成 & 例 \\
\hline $\mathrm{Zn}-\mathrm{Co}$ & \multirow{3}{*}{\multicolumn{3}{|c|}{ 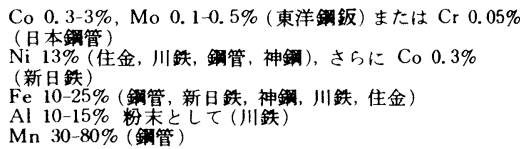 }} \\
\hline $\mathrm{Zn}-\mathrm{Ni}$ & & & \\
\hline $\begin{array}{l}\mathrm{Zn}-\mathrm{Fe} \\
\mathrm{Zn}-\mathrm{Al} \\
\mathrm{Zn}-\mathrm{Mn}\end{array}$ & & & \\
\hline
\end{tabular}

滑性がすぐれているだけでなく，热水，発油性がよく， プラスチック成型時の離型性とともに成型品の流動性を 向上させる効果がありプラスチック成型用の金型に使用 されているまた，めつき面を仕上げ研磨することによ つて各種のロールにも適用されている ${ }^{37}$.

EBDON $^{38)}$ は Ni-PTFE 分散めつきのすぐれた耐摩耗 性を利用して自動車部品, 機械部品, バルブ, ガラスビ ン製造用モールドなどのめつきに適用した。

TULSI ${ }^{39)}$ は化学ニッケルめつき浴にPTFE を分散阂 として用い, Ni-PTFE 分散めつきの耐摩耗性, 潤滑性 について検討を行つている.

本間ら ${ }^{40)}$ は化学めつき法による Ni-P-BN 分散めつき 皮膜が Ni-P, Ni-P-SiC, 硬質クロムめつきあるいはテ フロン加工したクロムめつきより低摩擦係数を有するこ とを明らかにした。

\section{5. 耐食性めつき皮膜}

鉄鋼材料に対する防食めつき皮膜としては従来から亜 鉛, カドミウムなどの犠牲溶解型のめつき皮膜が工業的 に用いられている、とくに，垔鉛めつき鋼板については 最近，自動車用の防錆めつき鋼板として各種の新しい亜 鉛合金めつき鋼板が開発されている.公表されている垔 鉛合金めつき鋼板の種類を表 3 に示す41).

また，ラック用の電気めつき浴として開発された亜鉛一 ニッケル合金めつきは 5-10\%の Niを含み, 純亜鉛め つきに比べ 3 倍以上の耐食性が得られている42). さら に, 0.2-0.4\% の Co を含む Zn-Co 合金めつきもク口 メート処理を行らことによつて耐食性が著しく向上する ことが認められている43).

平松ら ${ }^{44)}$ はシランカップリング処理を行つた $\mathrm{Zn}-\mathrm{SiO}_{2}$ 分散めつきの耐食性を塩水噴霧試験法により調ベ, シラ 
ソカップリングによつて $\mathrm{Zn}-\mathrm{SiO}_{2}$ 分散めつきの耐食性 が著しく向上することを見出した。

内藤ら ${ }^{45)}$ は严鉛めつき鋼板の塗装性を向上させるため に塗装に用いられる高分子と親和性のよい有機高分子粒 子による亜鉛一有機高分子分散めつき法を開発した．分 散粒子としてはエポキシ樹脂, スチレン・ブタジェン共 重合体，フェノール樹脂などが用いられている。

めつき皮膜自体の耐食性に注目しためつき皮膜として は従来から多層めつきとしての $\mathrm{Ni}$ 上の $\mathrm{Cr}$ めきが帇 用化されているが，近年合金めつきについての関心が高 まり各種のめつき皮膜について検討されている。

ステンレススチール型の $\mathrm{Cr}-\mathrm{Ni}-\mathrm{Fe}$ 合金めつきは皮 膜自体の耐食性によつて素地金属の防錆効果が期待さ れ，多くの研究が行われている.

$\mathrm{Cr}-\mathrm{Ni}-\mathrm{Fe}$ 合金めつき皮膜の欠点は皮膜にクラックを 発生しやすいことで, $\mathrm{Cr}-\mathrm{Ni}-\mathrm{Fe}$ 合金めつきのみで素材 の鉄鋼材料を防食するという目的にはなお多くの問題が あるように思われる。

林ら ${ }^{46)}$ は 3 価クロム浴を用いた $\mathrm{Cr}-\mathrm{Ni}-\mathrm{Fe}$ 合金めつき の析出条件，皮膜の組成，特性について検討している が，18Cr-8Ni-Fe 合金めつきにおいてもクラックの発 生が耐食性皮膜としての実用化に障害となつている. $\mathrm{Cr}-\mathrm{Ni}-\mathrm{Fe}$ 合金めつきの作製にパルス電解法を適用する ことによつてある程度クラックの発生を防止でき，皮膜 の耐食性が向上することが認められている.

KAMMEL 5 47) 48) も各種のめつき浴について $\mathrm{Cr}-\mathrm{Ni}$ $\mathrm{Fe}$ 合金めつきの析出条件，皮膜の特性を検討している が，この場合にもクラックの発生が問題となつていると いわれる。

LASHMORE ら ${ }^{49)}$ は $\mathrm{Cr}-\mathrm{Ni}$ 合金めつきの電解条件とし てパルス電解法を適用することにより，クラックの少な い耐食性のよい $\mathrm{Cr}-\mathrm{Ni}$ 合金めつき皮膜を得ている。

鉄鋼材料に対する防食皮膜としてアルミニウムめつき が注目され，最近ドイッのシェンプ・デッカー社ならび にオランダのフィリップス社により非水溶媒浴が工業化 された。

フィリップス社のアルミニウムめつき浴は常温タイプ の $\mathrm{AlCl}_{3}-\mathrm{LiAlH}_{4}-\mathrm{THF}$ 浴 $\left(20-30^{\circ} \mathrm{C}\right)$ で線材の連続め つき装置も試作されている50).

シェンプ・デッカー社のめつき浴はZiegler 型の

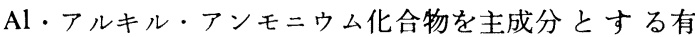
機溶媒浴 $\left(80-100^{\circ} \mathrm{C}\right)$ で $15000 l$ の大型のラック用ハ イロットプラントが稼動している51).

\section{6. 電気接点用めつき皮膜}

金めつきは電導性がよく，接触抵抗が小さく，また， 耐食性もよいので各種の電子部品は接点材料として用い られている. とくに, すべり接触面を持つ接点には耐摩 耗性が要求されるので, 少量の Co p $\mathrm{Ni}$ を共析させ
た硬質金めつきが用いられている.

LARSON 552) 粒子（粒径 $1 \mu \mathrm{m}$ ) を金めつき中に共析させ, $\mathrm{Au}-\mathrm{TiC}$, Au-WC の分散めつきを作製しているが，いずれも硬 さ，強度およびすべり摩耗特性が純粋な金めつきょり向 上し, 特に Au-WG 分散めつき（WC 17\% 含有） は $800^{\circ} \mathrm{C}$ の熱処理後も純粋な金めつきより 1.5 倍も硬く, 接触抵抗が $1.08 \mathrm{~m} \Omega$ で金めつきの $0.78 \mathrm{~m} \Omega$ に近いこと が認められている.

銀めつきへの $\mathrm{MoS}_{2}, \mathrm{BN}, \mathrm{Al}_{2} \mathrm{O}_{3}, \mathrm{TiO}_{2}$ などの共析 による分散めつきも電気接点の耐食性, 耐スパークエロ ージョン性，耐摩耗性を向上させることが報告されてい る.

通常，銅，黄銅を素材とする電気接点には耐食性，耐 摩耗性を向上させるためにパラジウムめつきが行われて いる.このよらなパラジウムにグラファイト粒子を分散 共析させると，めつき皮膜の耐食性が著しく向上するこ とが報告されている53).

また，金めつきの下地めつきとして光沢ニッケルめつ きの代わりに Ni-Sn 合金めつきを行うことによつて, 薄い金めつきで接点特性のすぐれた製品が得られてい $ろ^{54)}$.

\section{7. 磁性合金めつき}

機能めつきの最も代表的なものとして磁性合金めつき 薄膜があげられる．磁性合金めつきはその特性によつて a) 軟磁性薄膜と b ) 硬磁性材料に大別され，前者は 20-50 Oe の保磁力をもつ Ni-Fe (80-20) 合金めつき (パーマロイ）および $\mathrm{Fe}-\mathrm{Ni}$ (97-3) などがあり，コン ピューターメモリ一用に用いられている. 一方, 後者は $200 \mathrm{Oe}$ 以上の保磁力を有し, コンピューター, 音声, および映像の記録用に用いられ，Co-P, Ni-Co-P など の化学めつき皮膜がある.

最近, Co-Zn-P, Co-Ni-Mn-P, Co-Mn-Re-Pなど の化学めつき法によるコバルト合金薄膜は高密度磁気記 録媒体として注目されている55).

\section{8. ソーラーコレクター用黒色めつき}

太陽熱選択吸収皮膜としてはすでに黒色ニッケル，黒 色クロム, 黒色すずーコバルトめつき, 亜鉛めつきの黒色 クロメート処理, 化学ニッケルめつきの化成処理などが 検討されているが，めつき皮膜の耐食性，選択吸収特性 などを考慮するとニッケルめつき上の黒色クロムめつき が最良のシステムと考えられる56).

最近， 3 価ク口ムめつき浴を用いる黒色 $\mathbf{C r}-\mathbf{C o}$ 合金 めつきが開発され，その選択吸収特性も黒色ク口ムめつ きとほぼ同じものが得られている57).

なお，ソーラーコレクター用黒色めつき皮膜としては 黒色乇リブデンめつき ${ }^{58)}$, 黒色 $\mathrm{Sn}-\mathrm{Ni}-\mathrm{Mo}$ めつき59)な 


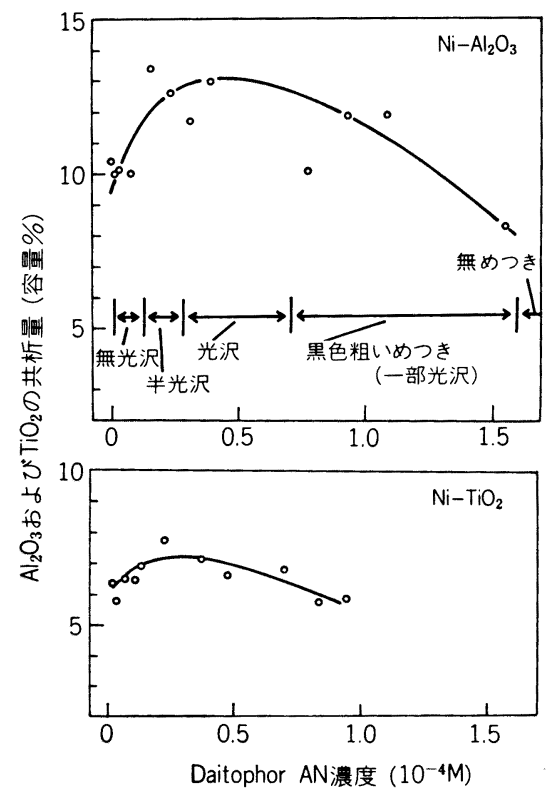

因 $8 \mathrm{Al}_{2} \mathrm{O}_{3}$ の共析に及ほす界面活性郕 Daitophov AN の影響60)

どについても検討されている.

\section{9. カラーめつき}

一般に分散めつき浴に界面活性剤を添加すると分散剂 粒子の共析反応を促進する効果のあることはよく知られ ている. 林ら ${ }^{60)}$ は $\mathrm{Al}_{2} \mathrm{O}_{3}$ を分散剂とする $\mathrm{Ni}-\mathrm{Al}_{2} \mathrm{O}_{3}$ 分 散めつきの作製において蛍光性の強いカチオン界面活性 剂, Daitophor AN (大東化学工業(株)製) をめつき浴 に添加することによつてニッケルめつきに特有の色調 （蛍光性）を与えよらとする実験を行つた．図 8 に Ni$\mathrm{Al}_{2} \mathrm{O}_{3}$ 分散めつきの $\mathrm{Al}_{2} \mathrm{O}_{3}$ 共析量およびめつき皮膜の 表面状態の変化を示す.

このよらな $\mathrm{Ni}-\mathrm{Al}_{2} \mathrm{O}_{3}$ 分散めつき系では $\mathrm{Al}_{2} \mathrm{O}_{3}$ に吸 着した蛍光性の界面活性剂だけでは十分な蛍光特性が得 られなかつたので，分散剤自体が蛍光性をもつ有機蛍光 性顔料を用いて分散めつき法による蛍光性カラーニッヶ ルめつきの生成条件を検討した ${ }^{61)}$.

ニッケルめつき浴にワット浴を用い, 分散荗粒子とし てメラミン樹脂系の蛍光顔料シンロイヒカラー FZ（大 日本塗料-シンロイヒ (株) 製, 平均粒径 3.5-4.5 $\mu \mathrm{m}, レ$ モンイエロー，オレンジ，グリーン，ピンク）を用い た.このよらな方法で得られた分散めつきの表面はいず れの蛍光顔料を用いても顔料と同じ色調を与え，また紫 外線によつて強い蛍光を発することが認められた。

なお，蛍光粒子の脱落を防ぎ，カラーおつきとしての 特徵を生かすために, 最終仕上げとして分散めつき上に $\mathrm{Ni}, \mathrm{Cr}$ あるいは $\mathrm{Au}$ などの薄いめつき $(0.2-5 \mu \mathrm{m})$ を
行らことにより金属蛍光板としての特性が得られた.

\section{0.むす び}

機能性金属めつきの代表的なものについて最近の動向 を述べたが，防錆めつきとしての亜鉛合金めつきおよび アルミニウムめつきなど今後新しいめつき技術の開発が 望まれる. とくに，非水溶媒浴を用いるアルミニウムめ つきの工業化はこれからの課題といえる.

分散めつきは金属マトリックスと分散剤との組合せに よつて，従来の金属めつきでは達成されないよらな新し い機能めつきの出現が期待されるとともに, 寸でに実用 化されている耐摩耗, 耐摩擦性を目的とした分散めつき はさらに新しい機械部品へ適用されるものと考えられ る.

合金めつきについても耐食性，耐熱性のすぐれた NiCr あるいは $\mathrm{Cr}-\mathrm{Ni}-\mathrm{Fe}$ 合金めつき法の確立が望まれ る.

\section{交献}

1) 林忠夫：電気化学が拓く将来技術（第 26 回電 気化学七ミナー (1985), p. 79 [電気化学協会関 西支部]

2) U. Ruml : Metalloberfläche, 23 (1969), p. 35

3 ) $W$. Metzger and $R$. Ott: ibid., 31 (1977), p. 404

4) $H$. Hübner and $A$. Ostermann: Galvanotechnik, 67 (1976), p. 452

5 ）石森茂, 清水 充, 本田信一, 大榢信治郎, 豊 田正義：金属表面技術，28(1977)，p. 508

6 ) $S$. Ishimori, $S$. Otsuka and $M$. Takama: Proc. 71st AES Annual Technical Conference (1984), O-5

7) W. Metzger, H.-H. Tombrink and $T h$. Florian: Metalloberfläche, 32 (1978), p. 180

8 ) $W$. Metzger and $T h$. Florian: ibid., 34 (1980), p. 274

9) E. Broszeit: Thin Solid Films, 95 (1982), p. 133

10) M. Ghouse: Surface Tech., 21 (1984), p. 193

11）小見崇，山本 久：金属表面技術，34(1983)， p. 416

12) $E . C$. Kedward, $C . A$. Addison and $A . A . B$. Tennetr: Trans. Inst. Metal Finishing, 54 (1976), p. 8

13) E. $C$. KedWARd and $K . W$. Wright: Plating and Surface Finishing, 65 (1978) 8, p. 38

14) $M$. ThomA and $P$. BüNger: Galvanotechnik, 75 (1984), p. 425

15) M. Tнома: Plating and Surface Finishing, 71 (1984) 9, p. 51

16) G. Gawrilov and Chr. ERININ: Galvanotechnik, 66 (1975), p. 397

17) $N$. Feldstein, $T$. Lancsék, $R$. Barras, $R$. Spencer and $N$. Bailey: Products Finishing, 44 (1980) 7, p. 65

18) $N$. Feldstein, $T$. Lancsek, $D$. Lindsay and L. Salorno: Metal Finishing, 81 (1983) 8, p. 35 
19) D. J. Kenton, W. L. Lawson and $R$. E. Zugnoni: Proc. 1st AES Electroplating Symposium (1982)

20) J. K. Dennis, $S . T$. Sheikh and $E . C$. Silverstone: Trans. Inst. Metal Finishing, 59 (1981), p. 118

21) L. D. Brown: Trans. Inst. Metal Finishing, 62 (1984), p. 139

22) $N$. Furukawa and T. Hayashi: Proc. 71 st AES Annual Tech. Conference, (1984), Q-2

23) 古川直治, 尾形順司, 林 忠夫：電気化学, 51 (1983), p. 171

24）古川直治，林 忠夫：金属表面技術協会第 69 回 講演大会要旨集 (1984), p. 86

25) A. E. Grazen: Iron Age, 183 (1959) 5, p. 94

26) J. C. Withers: Products Finishing, 26 (1962) 11, p. 62

27) D. S. Brown and $K$. V. Gow: Plating, 59 (1972), p. 437

28) J. P. Gelis and J.R. Roos: J. Electrochem. Soc., 124 (1977), p. 1508

29) $G$. $R$. Lakshminarayanan, $E$. S. Chen and F. K. Sauter: Plating and Surface Finishing, 63 (1976) 5, p. 35

30) J. R. Roos, J. P. Celis and J. A. Helsen: Trans. Inst. Metal Finishing, 55 (1977), p. 113

31) G. C. Pini and J. Weber: Proc. 9th World Congress on Metal Finishing, (1976)

32) G. E. Vest and D. F. Bazzarre: Metal Finishing, 65 (1967) 11, p. 52

33）黑崎重彦：材料加工 (1973) 6, p. 32

34) 山口文雄, 黒崎重彦, 渡辺信淳: 電気化学, 43 (1975), p. 106

35）大高徽雄：実務表面技術，29（1982），p. 304

36）梅田洋一，杉谷泰夫，三浦 実，中井 健：鉄と 鋼, $67(1981)$, p. 1377

37) $K$. Naitoh and $T$. Otaka: New Materials \& New Processes, 1 (1980), p. 170

38) P. R. Ebdon: Proc. 71 st AES Tech. Conference (1984) O-6

39) S. S. TulsI: Trans. Inst. Metal Finishing, 61 (1983), p. 147

40) $H$. Honma, $N$. Ohtake and $H$. Mitzui: Proc. 10th World Congress on Metal Finishing, (1980), p. 241
41）乾 恒夫，安谷屋武志：鉄と鋼, 71 (1985), p. 520

42）上谷正明，君塚亮一：金属表面技術協会第 69 回 学術講演大会要旨集 (1984), p. 10

43) $E$. KnaAK, $H$. Köhler and $I$. Hadley: Metalloberfläche, 33 (1985), p. 139

44）平松実，川崎仁士，草野文男：金属表面技術協 会第 71 回講演大会要旨集 (1985)，p. 35

45) 内藤邦子, 出口和夫, 久保光康, 黒崎重彦：金属 表面技術, 28(1977), p. 291， p. 325，p. 517

46) $T$. Hayashi and $A$. Ishinama: Plating and Surface Finishing, 66 (1979), p. 36

47) 柿原清貴, 登内 明, 影近 博, 福本幸男, $R$. KAMMEl：金属表面技術協会第 72 回大会講演 要旨集 (1985)

48) 松岡政夫, $R$. KAMMEL and $U$. LANDAU : 同上 (1985)

49) D. S. Lashmore and $I$. Weisshaus: Proc. 11th World Congress on Metal Finishing (1984) p. 356

50) J. F. M. van de Berg, G. van DijK and R. E. van de LeEst: Metal Finishing (1985) 5, p. 15

51) Schempp+Decker 社カタログ (1985)

52) C. Larson: Electroplating and Metal Finishing, 29 (1976), 1 p. 12

53) R. S. SAIfLiN: Ref. Zurnal (USSR), 66 (1977), p. 40

54) 榎本英彦, 石川正已：金属表面技術，30(1979), p. 284

55) $T$. Osaka, $N$. Kasai, $I$. Koiwa, $F$. Goto and $Y$. Suganuma: J. Electrochem. Soc., 130 (1983), p. 568

56) H. Meissner: Metalloberfläche, 34 (1980), p. 421

57) $M$. Iкомa, $Y$. Fukumoto and $T$. Hayashi: Metal Finishing, 82 (1984) 2, p. 79

58) R. Hossein: Surface Tech., 20 (1983), p. 321

59) $S$. Ueda, $Y$. Ohbayashi, $T$. Ohsaka and $T$. Shikata: Proc. 11th World Congress on Metal Finishing (1984), p. 94

60) $T$. Hayashi, $N$. Maeda and $N$. Furukawa: Proc. 9th World Congress on Metal Finishing (1976)

61）古川直治，林 忠夫：金属表面技術，31 (1980), p. 576 